\title{
EFFECT OF DRYING CONDITIONS AND EXTRACTION SOLVENTS ON TOTAL PHENOLIC COMPOUNDS AND ANTIOXIDANT PROPERTIES OF MANGO SEED KERNEL EXTRACTS \\ Mehriz, A.M. ; M.A. Azzam ${ }^{*}$; N.A.Youniss ${ }^{* *}$ and S.A.Osman ${ }^{* *}$ \\ * Dairy Sci. Dept., Fac. Agric. Cairo Univ., Giza, Egypt. \\ ** Dairy Tech. Dept., Animal Production Res. Inst., Dokki, Giza, Egypt.
}

\begin{abstract}
Mango seeds are a by-product of fruit factories that have low economic value. But, its high phenolic content makes it to be important source of natural antioxidants. The effect of drying methods (sun-drying and oven-drying at $50{ }^{\circ} \mathrm{C}$ ) and extraction solvents (chloroform / methanol mixture $(2: 1, \mathrm{v} / \mathrm{v}), 80 \%$ ethanol and water) on total phenolics and antioxidant properties of mango seed kernel extracts (MSKE) were studied. Results showed that the combination of oven-drying and chloroform / methanol mixture $(2: 1, \mathrm{v} / \mathrm{v})$ extraction was the most effective recovery method in relation to the yield of gained dried matter (15.17\%), and quantity of extracted total phenolics per gram of extractable dry matter (102.5 mg). Antioxidant properties expressed as antioxidant index calculated from the ratio of induction period (time taken in hours to reach a peroxide value of 5 during storage at $80 \pm 2^{\circ} \mathrm{C}$ ) of buffalo ghee sample treated with $5 \%(\mathrm{w} / \mathrm{v})$ of MSKE concentrated liquid obtained from using oven-dried mango seed kernel and chloroform / methanol mixture extraction to induction period of control sample was 4.52 , compared to 3.23 when $0.02 \%$ BHT was used. Using HPLC, nine phenolic compounds identified in oven-dried mango seed kernel extract resulted from chloroform / methanol mixture extraction method were qurecetin, catechin, vanillin, coumarin, tannin, rutin and cinammic, ferulic, and gallic, acids. It could be concluded that mango seed kernel powder can serve as potential source of natural antioxidants for application in food products due to their marked antioxidant properties.
\end{abstract}

Keywords: Mango seed kernel extract; phenolic compounds; antioxidant properties; buffalo ghee; synthetic antioxidant; butylated hydroxyl toluene (BHT).

\section{INTRODUCTION}

The importance of antioxidants for food applications has been underlined by numerous works. Synthetic antioxidants, such as butylated hydroxy anisole (BHA), butylated hydroxy toluene (BHT) and t- butyl hydroquinone (TBHQ) are widely used because they are effective and cheaper than natural types. However, the safety and toxicity of synthetic antioxidants are of important concerns (Imaida et al., 1983). Much attention has been focused on the use of natural antioxidants, to inhibit lipid peroxidation or to protect the human body from the oxidative damage by free radicals. Recently, a multitude of natural antioxidants have already been isolated from agricultural wastes such as solid wastes generated from the processing of vegetables and fruits, which cause serious environmental problems, such as water pollution, unpleasant odors and explosions and combustion (Zamorano et al., 2007). For instance, there are several million tons of mango seed wastes produced annually from the factories in Egypt. 
These wastes must convert into value- added applications. One of these applications is to reuse of mango seed wastes as a low- cost source of natural antioxidants (Abdalla et al. 2007a).

Several studies have shown that mango seed kernels contain various phenolic compounds. Gallotannins and condensed tannin- related polyphenols were reported to be present in mango kernels (Arogba, 1997). In addition, polyphenols from dry mango kernel meal were found to contain tannic acid, gallic acid, and epicatechin in the ratio 17:10:1, respectively (Arogba, 2000). Abdalla et al. (2007a) have recently characterized the phenolic compounds in Egyptian mango seed kernels. The components included tannins, gallic acid, coumarin, ellagic acid, vanillin, mangiferin, ferulic acid, cinammic acid and unknown compounds.

The properties (e.g. antioxidant activity) of extracts from plants were found to be depent on the extraction solvents used (Durling et al., 2007; Lim and Murtijaya, 2007 and Spigno and De Faveri, 2007). Water, methanol, ethanol are commonly used to extract phyto-chemicals from plants due to the absence of toxicity. Since drying of mango seed kernels in the factory either by sun-drying or hot air oven-drying could reduce storage volume and extend their shelf life. Therefore, the objective of this study was to evaluate the effects of drying methods and extraction solvents on the total phenolics and antioxidant properties of mango seed kernel extracts to obtain a natural antioxidant that could be a synthetic antioxidant replacer in ghee preservation.

\section{MATERIALS AND METHODS}

Butter samples prepared from fresh raw cream obtained from fresh raw buffalo milk were heat clarified to ghee until the temperature reached $115^{\circ} \mathrm{C}$. Five kilograms of mango (Mangifera indica $\mathrm{L}$ - Alphonso) seeds as waste were collected from private local fruit juice processing units at Giza, Egypt.

All chemicals used in this study were purchased from El-Gomhouria Co. for chemicals and medical requisites (Al-ameria, Cairo, Egypt), while butylated hydroxy toluene (BHT) was procured from Sigma (St. Louis, MO, USA).

The seeds were washed and peeled. The kernels were divided into two portions, the first was sun- dried in a green house for three days, and the second was dried in a hot air- oven at $50^{\circ} \mathrm{C}$ until a constant weight was attained (approximately six hrs in case of the last method). The dried kernels were chopped and ground in a stainless- steel grinder into fine powder, passed through a 60 - mesh sieve and kept in closed dark glass bottles at $4^{\circ} \mathrm{C}$ until utilization.

Two solvents, $80 \%$ ethanol and chloroform / methanol mixture (2:1, v/v) were separately used to extract phenolics from mango seed kernels. 100 milliliters of each solvent were added to a flask containing $50 \mathrm{~g}$ of sun- dried or oven- dried material. Each flask was wrapped by aluminum foil to prevent light degradation during extraction. The flasks were shaken overnight at room temperature. Another 50 grams of sun- dried or oven- dried material were 
stirred with deionized water $(100 \mathrm{ml})$ at room temperature for $15 \mathrm{~min}$ as a third solvent. All mixtures were filtered through Whatman filter paper No 41 to obtain crude extracts according to the method of Puravankara et al., (2000).

Each solvent's crude extract filtrate was mixed with an equal volume of both distilled water and chloroform separately, and then the aqueous and organic phases were separated using a separation funnel.

Each aqueous layer containing all hydrophilic compounds obtained from all of the examined solvents was mixed with an equal volume of ethyl acetate. This step was repeated three times. After partitioning and phase separation, the top layers (ethyl acetate layers) were collected together and vacuum evaporated in a rotary flask evaporator to about $20 \mathrm{ml}$ as described by Puravankara et al., (2000). All concentrated extracts were kept in a closed dark glass bottles at $4^{\circ} \mathrm{C}$ until utilization.

The mango seed kernel powder (MSKP) was analyzed for moisture, protein, fat, fiber and ash following the methods specified by AOAC (1990), and the carbohydrate content was calculated by difference. The total phenolic content of mango seed kernel extracts (MSKE) was determined using FolinCiocalteu's phenol reagent as shown by Slinkard and Singleton (1977). Briefly, $20 \mu \mathrm{l}$ of concentrated extract were mixed thoroughly with $1.16 \mathrm{ml}$ distilled water and $100 \mu \mathrm{l}$ of Folin- Ciocalteu phenol reagent. After mixing for $3 \mathrm{~min}, 300 \mu \mathrm{l}$ of $\mathrm{Na}_{2} \mathrm{CO}_{3}$ solution $(20 \% \mathrm{w} / \mathrm{v})$ was added. The mixture was incubated in a shaking incubator at $40^{\circ} \mathrm{C}$ for $30 \mathrm{~min}$, thereafter its optical density (O.D.) was measured at $765 \mathrm{~nm}$. Gallic acid was used as a standard. The phenolic content was expressed as gallic acid equivalent using the linear equation based on the following standard curve as shown in Fig (1).

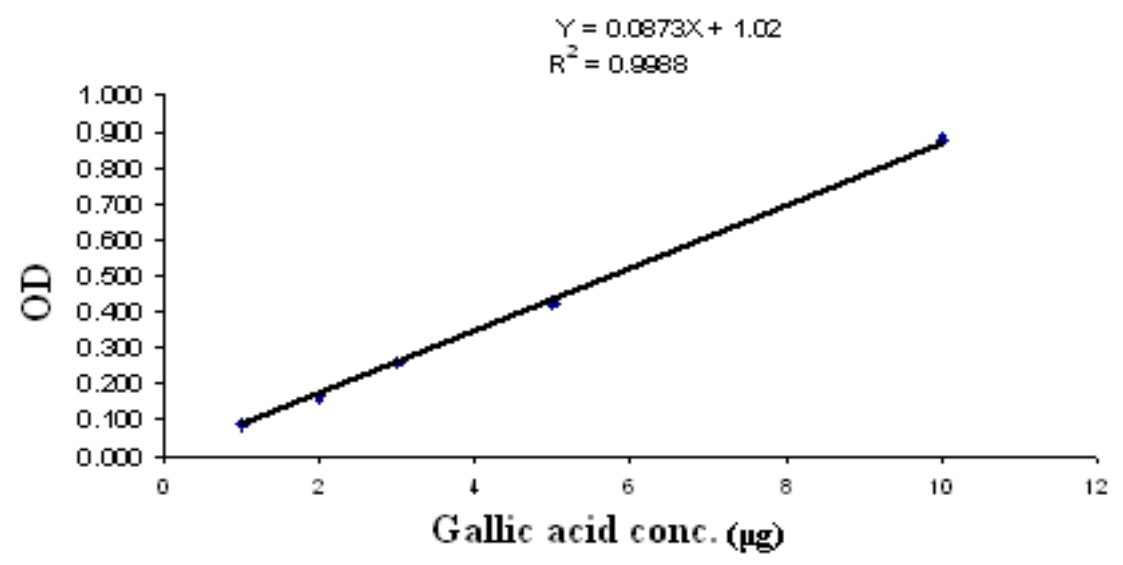

Fig. (1): Gallic acid standard curve

The phenolic compounds of the MSKE containing the highest total phenolic content were identified using high performance liquid chromatography (HPLC) according to the method described by Anderson and Pederson (1983). HPLC (Hewlett Packard Series HP 2100, UK) consisting of a model P 4600 pump with a Waters R401 detector, a U6K injector, and a Waters Bondapak C-18 column $(30 \mathrm{~cm} \times 4 \mathrm{~mm})$ was used. 
Sun- and oven- dried MSKEs were added separately to $200 \mathrm{~g}$ of freshly prepared buffalo ghee samples at levels of $0.5,1,3$ and $5 \%(\mathrm{w} / \mathrm{v})$. For comparison, the permitted synthetic antioxidant butylated hydroxy toluene (BHT) was added at $0.02 \%(\mathrm{w} / \mathrm{v})$. The buffalo ghee samples with and without additives (control) were packed separately into screw capped $250 \mathrm{ml}$ glass jars, covered externally with aluminum foil, and subjected to accelerated oxidation in an oven maintained at $80 \pm 2^{\circ} \mathrm{C}$. Antioxidant properties of these samples were evaluated by monitoring their peroxide development at intervals of 12 hrs to record the time taken in hours to reach a peroxide value of 5 , since, the ghee samples were presumed to be deteriorated after a peroxide value of 5 at $80^{\circ} \mathrm{C}$ (Parmar and Sharma, 1990).

Peroxide value (meq. $\mathrm{O}_{2} / \mathrm{kg}$ ghee) was determined according to AOCS (1989). To test the effectiveness of the additives, antioxidant indices were calculated according to Pruthi et al., (1970). All tests were carried out in triplicate and average of results was presented.

The obtained data were statistically analyzed using $2 \times 3$ factorial design. Duncan's test was used to make the multiple comparisons (Steel and Torri, 1980). Significant differences were determined at $P<0.05$.

\section{RESULTS AND DISCUSSION}

The major composition of mango seed kernel powder(MSKP) presented in Table (1) indicated that the dry matter content of oven- dried mango seed kernel powder samples (ODMSK) (96.24\%) was higher than that of sun- dried mango seed kernel powder samples (SDMSK) (93.89\%). This was due to the use of steady and continuous heating in an oven during drying of mango seed kernels, which caused loss of accessible of their moisture. Consequently, ODMSK had higher solid compounds such as protein, fat, fiber, ash and carbohydrates $(6.3,11.1,2.5,2.1$ and $78 \%$ on a dry weight basis, respectively). These results were in agreement with the data obtained by Zein et al. (2005), and Abdalla et al. (2007a).

Table (1): Effect of drying conditions of mango seed kernels on their chemical composition 1 .

\begin{tabular}{|l|c|c|c|c|c|c|}
\hline \multirow{3}{*}{ Samples } & \multicolumn{7}{|c|}{ Chemical composition } \\
\cline { 2 - 7 } & $\begin{array}{c}\text { Dry matter } \\
\%\end{array}$ & $\begin{array}{c}\text { Protein } \\
\%\end{array}$ & $\begin{array}{c}\text { Fat } \\
\%\end{array}$ & $\begin{array}{c}\text { Fiber } \\
\%\end{array}$ & $\begin{array}{c}\text { Ash } \\
\%\end{array}$ & $\begin{array}{c}\text { Carbohydrates } \\
\%\end{array}$ \\
\hline ODMSK $^{2}$ & 96.24 & 6.30 & 11.1 & 2.5 & 2.1 & 78 \\
SDMSK $^{3}$ & 93.89 & 4.57 & 9.9 & 1.4 & 1.8 & 82.33 \\
\hline
\end{tabular}

The yield and total phenolics of MSKP varied significantly, according to the drying conditions and solvent type (Tables 2\&3). The amount of extractable components expressed as percentage by weight of dry matter of MSKP ranged from $4.64 \%$ (sun drying + water extraction) to $15.17 \%$ (oven drying $+\mathrm{Ch} / \mathrm{MtOH}$ extraction) (Table 2). 
Table (2): Effects of drying conditions and extraction solvents on yield of extracted components of mango seed kernel powder

\begin{tabular}{|l|c|c|c|c|}
\hline \multirow{2}{*}{ Drying method } & \multicolumn{3}{|c|}{ Yield of extracted components } & \multirow{2}{*}{ Mean } \\
\cline { 2 - 4 } & \multicolumn{3}{|c|}{ Extraction solvents } & \\
Sun-drying & Chl/MtOH & $\mathbf{8 0 \%}$ Ethanol & Water & \\
Oven-drying & $8.75^{\mathrm{d}} \pm 0.16$ & $12.84^{\mathrm{b}} \pm 0.08$ & $4.64^{\dagger} \pm 0.20$ & $8.74 \pm 1.19$ \\
Mean & $15.17^{\mathrm{a}} \pm 0.03$ & $10.32^{\mathrm{c}} \pm 0.13$ & $6.11^{\mathrm{e}} \pm 0.03$ & $10.53 \pm 1.31$ \\
\hline
\end{tabular}

${ }^{*}$ Grams of extracted components per $100 \mathrm{~g}$ of dry matter in MSKP. \pm SE.

Superscripts a,b,c,d,e,f: means that the same letter among the treatments are not significantly different.

Drying method = Significant.

LSD value at 0.05 for Extraction solvents $=0.28$

LSD value at 0.05 for drying method $\times$ extraction solvents $=0.4$

The content of phenolic compounds (expressed as gallic acid equivalents) of MSKEs as affected by drying method and type of solvent used was in the order: ODMSK $(\mathrm{Chl} / \mathrm{MtOH})>$ SDMSK $(\mathrm{EtOH})>$ ODMSK $(\mathrm{EtOH})>$ SDMSK Chl/MtOH) $>$ ODMSK $\left(\mathrm{H}_{2} \mathrm{O}\right)>\operatorname{SDMSK}\left(\mathrm{H}_{2} \mathrm{O}\right)($ Table 3$)$.

Table (3): Effects of drying conditions and extraction solvents on total phenolic content of mango seed kernel powder *

\begin{tabular}{|l|c|c|c|c|}
\hline \multirow{2}{*}{ Drying method } & \multicolumn{3}{|c|}{ Yield of extracted phenolices } & \multirow{2}{*}{ Mean } \\
\cline { 2 - 4 } & \multicolumn{3}{|c|}{ Extraction solvents } & \\
\hline & Chl/MtOH & $\mathbf{8 0 \%}$ Ethanol & Water & \\
Sun-drying & $69.3^{\mathrm{d}} \pm 0.39$ & $80.8^{\mathrm{b}} \pm 0.28$ & $52.1^{\mathrm{f}} \pm 0.17$ & $67.4 \pm 4.17$ \\
Oven-drying & $102.5^{\mathrm{a}} \pm 0.18$ & $74.9^{\mathrm{c}} \pm 0.14$ & $60.9^{\mathrm{e}} \pm 0.05$ & $79.43 \pm 6.11$ \\
Mean & $85.9 \pm 5.23$ & $77.85 \pm 3.45$ & $56.5 \pm 4.22$ & \\
\hline
\end{tabular}

${ }^{*} \mathrm{mg}$ of gallic acid per 100 gram of dry matter in MSKP. \pm SE.

Superscripts a,b,c,d,e,f: means that the same letter among the treatments are not significantly different.

Drying method $=$ Significant

LSD value at 0.05 for extraction solvents $=0.52$

LSD value at 0.05 for drying method $\times$ extraction solvents $=0.73$

Oven-drying resulted in $47.9 \%$ higher total phenolics in chloroform/methanol extraction and $16.9 \%$ in water extraction than that of their corresponding results from sun-drying of MSK. This could be attributed to the degradation/ polymerization products of mango seed kernel polyphenols during oven-drying, which seem to be more soluble in chloroform/methanol mixture than water, and could react with Folin- Ciocalteu reagent to produce the blue color under alkaline conditions as stated by $\mathrm{Yu}$ et al., (2005).The obtaind results are also in partial agreement with the results of Nepote et al., (2002), who reported that during the drying of peanut skin in oven, products formed due to the Maillared reaction might contribute to the increase of total phenolics or phenolics- like complexes that contributed to higher absorbance readings.

It is worthy to note that solvents used for phenolics extraction also significantly affected the total phenolic concentration of MSKE, when equal volumes of solvents were used. Chloroform/methanol mixture was more effective in extracting phenolic compounds from ODMSK than both $80 \%$ 
ethanol and water. The total phenolics resulting from extraction by chloroform/methanol mixture was $102.5 \mathrm{mg} / \mathrm{g}$ dry matter extracted, whereas $80 \%$ ethanol extract and water resulted in 74.9 and $60.9 \mathrm{mg} / \mathrm{g}$ dry matter extracted from ODMSK, respectively. These levels were compatible to the results reported by Puravankara et al., (2000); Yu et al., (2005); Abdalla et al., (2007a) and Maisuthisakul and Gordon (2009).

Statistical analysis using ANOVA showed that there was a positive or negative effect for interaction between drying methods and extraction solvents, which indicated that drying method might enhance or reduce the extraction capability of solvent. For example, the extraction capability of chloroform / methanol mixture was enhanced by oven- drying method (102.5 $\mathrm{mg}$ galic acid/g dry matter extracted from MSK ) while, sun- drying method was the superior with $80 \%$ ethanol for extracting phenolic compounds from MSK (80.8 $\mathrm{mg}$ galic acid/g dry matter extracted).

These findings were in line with Puravankara et al., (2000); ArabshahiDelouee and Urooj (2007) and Maisuthisakul and Gordon, (2009) who found that solvents such as chloroform / methanol mixture, methanol or ethanol were the most effective in extracting phenolic compounds from MSK than water.

Antioxidant activity of mango seed kernel extracts (MSKE) is shown in Fig (2) and Table (4), It could be observed that 5\% ODMSKE (Chl/MtOH) added to ghee samples, followed by SDMSKE (EtOH) added to ghee samples at the same level showed a marked increase in the antioxidant activity (induction period, time taken in hours to reach a peroxide value of 5 meq. of peroxide oxygen per $\mathrm{kg}$ of ghee) which was higher than that of $0.02 \%$ $\mathrm{BHT}$ containing ghee samples. Such induction periods were $398 \mathrm{~h}$ and $345 \mathrm{~h}$ for ODMSK (Chl/MtOH) and SDMSK (EtOH) containing ghee samples, respectively. Whereas, induction periods of both ODMSK (EtOH) and SDMSK $(\mathrm{Chl} / \mathrm{MtOH})$ containing ghee samples at level $5 \%$ were 279.2 and $267 \mathrm{~h}$, respectively while that of $0.02 \% \mathrm{BHT}$ containing ghee samples was $284 \mathrm{~h}$. A noticeable decrease in induction periods of ghee samples mixed with ODMSK $\left(\mathrm{H}_{2} \mathrm{O}\right)$ or SDMSK $\left(\mathrm{H}_{2} \mathrm{O}\right)$ was observed as compared with all other treated samples, however, they showed higher induction periods than that of control sample at all levels $(93.1,102.6,107.1,140.2 \mathrm{~h}$ for ODMSK $\left(\mathrm{H}_{2} \mathrm{O}\right)$ containing ghee samples and 92, 101.6, 105.2, $127 \mathrm{~h}$ for SDMSK $\left(\mathrm{H}_{2} \mathrm{O}\right)$ containing ghee samples at $0.5,1,3$ and $5 \%$ respectively). The correspondent figure for the control treatment was $88 \mathrm{~h}$. The obtained results were in accordance with those of Arogba, (2000); Abdalla et al., (2007b) and Maisuthisakul and Gordon (2009) who, reported that the solvents used in extraction may affect the antioxidant activity of the extract, by their effect on the content and composition of the phenolic compounds extracted. Moreover, the obtained results revealed that the extraction with solvents such as chloroform / methanol mixture $(2: 1, \mathrm{v} / \mathrm{v})$ or $80 \%$ ethanol was enough to dissolve most of the antioxidant components from mango seed kernel to have high antioxidant activity which was in line with the results of Maisuthisakul and Gordon, (2009). 


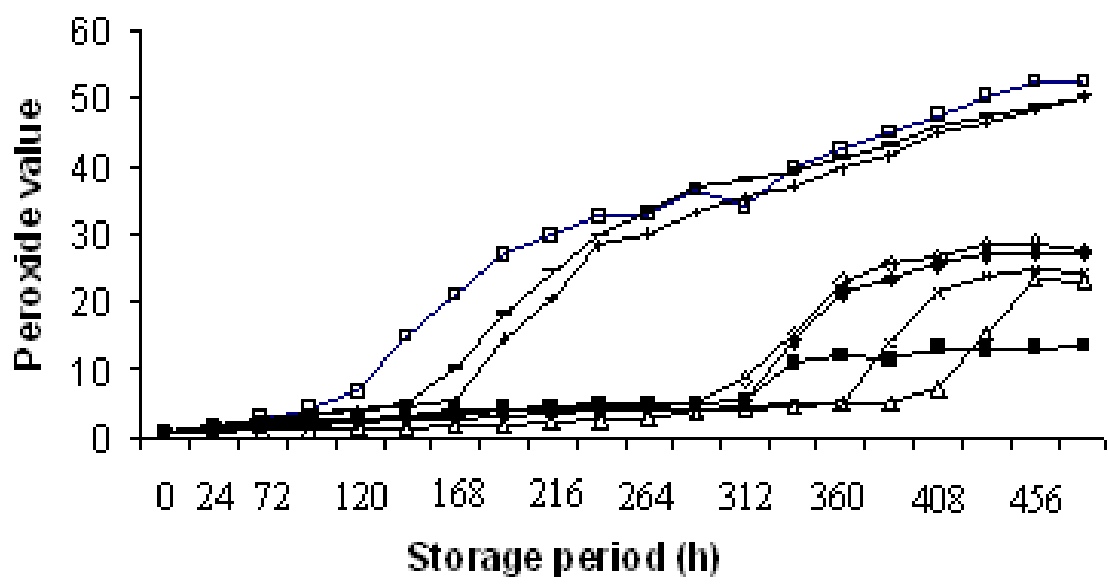

Fig. (2): Effect of addition $5 \%$ of mango seed kernel extracts (w/v) on the development of peroxide in ghee stored at $80^{\circ} \mathrm{C} \pm 2$. 口, Control; - , 0.02\% BHT; $\Delta$, ODMSK(Chl/MtOH); x,SDMSK(EtOH); ODMSK(EtOH); $\diamond$, SDMSK(Chl/MtOH); +, ODMSK( $\left.\mathrm{H}_{2} \mathrm{O}\right)$; -, SDMSK( $\left.\mathrm{H}_{2} \mathrm{O}\right)$.

Table (4): Induction period (hrs)of buffalo ghee as affected by addition of mango seed kernel extracts (MSKE) at various level (w/v) and $\mathrm{BHT}$ at $0.02 \%(\mathrm{w} / \mathrm{v})$.

\begin{tabular}{|c|c|c|c|c|c|c|c|c|}
\hline \multirow{3}{*}{\begin{tabular}{|c} 
Added \\
antioxidant \\
percentage \\
$(w / v)$
\end{tabular}} & \multicolumn{7}{|c|}{ Sources of extracted phenolics } & \multirow{3}{*}{ Control } \\
\hline & \multicolumn{2}{|c|}{$\begin{array}{c}\text { MSK } \\
\text { (Chl/MtOH) }\end{array}$} & \multicolumn{2}{|c|}{$\begin{array}{c}\text { MSK } \\
\text { (EtOH) }\end{array}$} & \multicolumn{2}{|c|}{$\begin{array}{l}\text { MSK } \\
\left(\mathrm{H}_{2} \mathrm{O}\right)\end{array}$} & \multirow{2}{*}{$\begin{array}{c}\text { BHT } \\
0.02 \\
\%\end{array}$} & \\
\hline & OD & SD & OD & SD & OD & SD & & \\
\hline 0.5 & $\begin{array}{c}101^{\mathrm{b}} \pm \\
0.20\end{array}$ & $\begin{array}{c}93.6^{e} \\
\pm \\
0.12\end{array}$ & $\begin{array}{c}96.1^{d} \\
\pm \\
0.15\end{array}$ & $\begin{array}{c}98^{c} \\
\pm \\
0.12\end{array}$ & $\begin{array}{c}93.1^{\text {ef }} \\
\pm \\
0.12\end{array}$ & $\begin{array}{c}92^{\dagger} \\
\pm \\
0.21\end{array}$ & $\begin{array}{c}284^{\mathrm{a}} \pm \\
0.05\end{array}$ & $\begin{array}{c}88^{9} \\
\pm \\
0.06\end{array}$ \\
\hline 1 & $\begin{array}{c}123.2^{\mathrm{b}} \\
\pm \\
0.23\end{array}$ & $\begin{array}{c}105^{\mathrm{e}} \\
\pm \\
0.15\end{array}$ & $\begin{array}{c}108.8^{d} \\
\pm \\
0.15\end{array}$ & $\begin{array}{c}112.4^{\mathrm{c}} \\
\pm \\
0.12\end{array}$ & $\begin{array}{c}102.6^{f} \\
\pm \\
0.29\end{array}$ & $\begin{array}{c}101.6^{f} \\
\pm \\
0.06\end{array}$ & $\begin{array}{c}284^{\mathrm{a}} \\
\pm \\
0.05\end{array}$ & $\begin{array}{c}88^{9} \\
\pm \\
0.06\end{array}$ \\
\hline 3 & $\begin{array}{c}131.1^{\mathrm{b}} \\
\pm \\
0.55\end{array}$ & $\begin{array}{c}112^{\mathrm{e}} \\
\pm \\
0.24\end{array}$ & $\begin{array}{c}115.2^{\mathrm{d}} \\
\pm \\
0.10\end{array}$ & $\begin{array}{c}122.2^{\mathrm{c}} \\
\pm \\
0.40\end{array}$ & $\begin{array}{c}107.1^{f} \\
\pm \\
0.24\end{array}$ & $\begin{array}{c}105.2^{g} \\
\pm \\
0.16\end{array}$ & $\begin{array}{c}284^{\mathrm{a}} \\
\pm \\
0.05\end{array}$ & $\begin{array}{c}88^{\mathrm{h}} \\
\pm \\
0.06\end{array}$ \\
\hline 5 & $\begin{array}{c}398^{a} \\
\pm \\
0.25\end{array}$ & $\begin{array}{c}267^{e} \\
\pm \\
0.17\end{array}$ & $\begin{array}{c}279.2^{\mathrm{d}} \\
\pm \\
0.23\end{array}$ & $\begin{array}{c}345^{\mathrm{b}} \\
\pm \\
0.06\end{array}$ & $\begin{array}{c}140.2^{f} \\
\pm \\
0.10\end{array}$ & $\begin{array}{c}127^{9} \\
\pm \\
0.06 \\
\end{array}$ & $\begin{array}{c}284^{c} \\
\pm \\
0.05 \\
\end{array}$ & $\begin{array}{c}88^{\mathrm{h}} \\
\pm \\
0.06\end{array}$ \\
\hline
\end{tabular}

OD = Oven dried. SD = Sun dried. \pm SE.

Superscripts a,b,c,d,e,f,g,h: means that the same letter among the treatments are not significantly different.

LSD value at $0.05:$ for $0.5 \%=1.43$

LSD value at 0.05 : for $1 \%=1.59$

LSD value at 0.05 : for $3 \%=0.87$

LSD value at $0.05:$ for $5 \%=1.48$.

For more real comparison of oxidative stability between the ghee samples mixed with MSKE and other mixed with BHT as synthetic antioxidant, and control sample, the results were expressed in terms of 
antioxidant index values (ratio of induction period of treated sample to induction period of control sample (Table 5).

The data in Table (5) indicated that the antioxidant index values of ghee samples treated with $5 \%$ solvents-MSKE other than $\mathrm{H}_{2} \mathrm{O}$ were comparable to those of $0.02 \% \mathrm{BHT}$. It is worthy to mention that, the antioxidant indices of ghee sample treated with $5 \%$ ODMSK $(\mathrm{Chl} / \mathrm{MtOH})$ followed by that treated with SDMSK $(\mathrm{EtOH})$ were superior as compared with sample treated with $0.02 \% \mathrm{BHT}$. On the other hand, the antioxidant index values of the ghee samples treated with 5\% ODMSK (EtOH) and SDMSK $(\mathrm{Chl} / \mathrm{MtOH})$ were slightly lower than that treated with BHT. Thus, the antioxidant indices for all treated samples with MSKE at $0.5,1,3$ or $5 \%(\mathrm{w} / \mathrm{v})$ were in order: ODMSK $(\mathrm{Chl} / \mathrm{MtOH})>\operatorname{SDMSK}(\mathrm{EtOH})>\mathrm{ODMSK}(\mathrm{EtOH})>$ $\operatorname{SDMSK}(\mathrm{Chl} / \mathrm{MtOH})>\mathrm{ODMSK}\left(\mathrm{H}_{2} \mathrm{O}\right)>\operatorname{SDMSK}\left(\mathrm{H}_{2} \mathrm{O}\right)$.

Table (5): Antioxidant index ${ }^{1}$ of buffalo ghee as affected by addition of mango seed kernel extracts (MSKE) at various levels (w/v) and $\mathrm{BHT}$ at $0.02 \%(w / v)$.

\begin{tabular}{|c|c|c|c|c|c|c|c|}
\hline \multirow{3}{*}{\begin{tabular}{|c} 
Added \\
antioxidant \\
percentage \\
$(w / v)$
\end{tabular}} & \multicolumn{6}{|c|}{ Sources of extracted phenolics } & \multirow{3}{*}{$\begin{array}{c}\text { BHT } \\
0.02 \\
\%\end{array}$} \\
\hline & \multicolumn{2}{|c|}{$\begin{array}{c}\text { MSK } \\
\text { (Chl/MtOH) }\end{array}$} & \multicolumn{2}{|c|}{$\begin{array}{c}\text { MSK } \\
\text { (EtOH) }\end{array}$} & \multicolumn{2}{|c|}{$\begin{array}{l}\text { MSK } \\
\left(\mathrm{H}_{2} \mathrm{O}\right) \\
\end{array}$} & \\
\hline & OD & SD & OD & SD & OD & SD & \\
\hline 0.5 & $\begin{array}{c}1.15^{\mathrm{b}} \pm \\
0.002\end{array}$ & $\begin{array}{c}1.06^{b c} \pm \\
0.002\end{array}$ & $\begin{array}{c}1.09^{b c} \pm \\
0.001\end{array}$ & $\begin{array}{c}1.11^{\mathrm{bc}} \pm \\
0.002\end{array}$ & $\begin{array}{c}1.06^{\mathrm{bc}} \pm \\
0.002\end{array}$ & $\begin{array}{c}1.05^{\mathrm{c}} \pm \\
0.003\end{array}$ & $\begin{array}{c}3.23^{a} \pm \\
0.003\end{array}$ \\
\hline 1 & $\begin{array}{c}1.40^{\mathrm{b}} \pm \\
0.002\end{array}$ & $\begin{array}{c}1.19^{\mathrm{c}} \pm \\
0.001\end{array}$ & $\begin{array}{c}1.24^{\mathrm{bc}} \pm \\
0.003\end{array}$ & $\begin{array}{c}1.28^{\mathrm{bc}} \pm \\
0.002\end{array}$ & $\begin{array}{c}1.17^{\mathrm{c}} \pm \\
0.004\end{array}$ & $\begin{array}{c}1.15^{\mathrm{c}} \pm \\
0.001\end{array}$ & $\begin{array}{c}3.23^{\mathrm{a}} \pm \\
0.003\end{array}$ \\
\hline 3 & $\begin{array}{l}1.49^{b} \pm \\
0.006\end{array}$ & \begin{tabular}{|c|}
$1.27^{\mathrm{de}} \pm$ \\
0.003 \\
\end{tabular} & $\begin{array}{l}1.31^{\text {cd }} \pm \\
0.001\end{array}$ & $\begin{array}{c}1.39^{\mathrm{bc}} \pm \\
0.004\end{array}$ & $\begin{array}{l}1.22^{\mathrm{de}} \pm \\
0.003\end{array}$ & $\begin{array}{c}1.20^{\mathrm{e}} \pm \\
0.002\end{array}$ & $\begin{array}{c}3.23^{\mathrm{a}} \pm \\
0.003\end{array}$ \\
\hline 5 & $\begin{array}{l}4.52^{\mathrm{a}} \pm \\
0.002\end{array}$ & $\begin{array}{l}3.03^{d} \pm \\
0.003\end{array}$ & $\begin{array}{c}3.17^{c} \pm \\
0.004\end{array}$ & $\begin{array}{c}3.92^{b} \pm \\
0.002\end{array}$ & $\begin{array}{l}1.59^{e} \pm \\
0.001\end{array}$ & $\begin{array}{l}1.44^{f} \pm \\
0.001\end{array}$ & $\begin{array}{c}3.23^{c} \pm \\
0.003\end{array}$ \\
\hline
\end{tabular}

1- Ratio of pre-deterioration period of treated sample to pre-deterioration period of control sample. \pm SE.

OD = Oven dried. SD = Sun dried.

Superscripts a,b,c,d,e,f: means that the same letter among the treatments are not significantly different.

$\begin{array}{ll}\text { LSD value at } 0.05: \text { for } 0.5 \%=0.1 & \text { LSD value at } 0.05: \text { for } 1 \%=0.18 \\ \text { LSD value at } 0.05: \text { for } 3 \%=0.11 & \text { LSD value at } 0.05: \text { for } 5 \%=0.14\end{array}$

HPLCSeparation of mango seed kernel extract, chromatogram indicating separation and identification of individual phenolic compounds in mango seed kernel extract (chloroform / methanol mixture -2:1, v/v) was shown in Fig (3). The results indicated that mango seed kernel (MSK) contained different phenolic compounds such as qurecetin, which represented $29 \%$ of total polyphenols, followed by $22 \%$ of catechin then $20 \%$ vanillin. MSKE also contained high amounts of coumarin and cinammic and ferulic acids, while gallic acid, tannin and rutin were found in lower amounts than other phenolic compounds. These results are in agreement with those reported by Abdalla et al. (2007a) and Mohamed and Girgis (2005) since Mohamed and Girgis (2005) separated six phenolic compounds, mainly coumaric,vanillin and ferulic acid, while Abdalla et al.(2007a) separated eight phenolic compounds. 




Fig. (3): HPLC chromatograms of mango seed kernel extract (Ch/MtOH). Peaks identified: 1.rutin, 2.catechin, 3.tannin, 4.coumarin, 5.cinnamic acid, 6.ferulic acid, 7.vanillin, 8.qurecetin, 9.gallic acid.

In conclusion, the results of this study indicated that mango seed kernel (MSK) was very rich in phenolics and its total phenolics content was as high as $52.1-102.5 \mathrm{mg} / \mathrm{gram}$ dry matter extracted from mango seed kernel, depending on drying conditions and extraction solvents. It could be concluded that using hot air oven-drying, and chloroform / methanol mixture $(2: 1, \mathrm{v} / \mathrm{v})$ extraction, is the most suitable procedure for the preparation of a mango seed kernel extract as natural antioxidant.

\section{REFERENCES}

Abdalla, A. E. M., Darwish, S. M., Ayad, E. H. E., and El-Hamahmy, R.M. (2007a).Egyptian mango by-product 1:Compositional quality of mango seed kernel. Food Chemistry, 103, 1134-1140.

Abdalla, A. E. M., Darwish, S. M., Ayad, E. H. E., and El-Hamahmy, R.M. (2007b).Egyptian mango by-product 2: Antioxidant and antimicrobial activities of extract and oil from mango seed kernel. Food Chemistry, $103,1141-1152$.

Anderson, J. M., and Pederson, W. B. (1983). Analysis of plant phenolics by HPLC. Journal of Chromatography, 259, 131-139.

AOAC, 1990. Official methods of analysis (15th ed.). Arlington, VA: Association of Official Analytical Chemists.

AOCS (1989). Official methods and recommended Practices (15th ed.) Champaign, New York: American Oil Chemist's Society. 
Arabshahi-Delouee, S. and Urooj A. (2007). Antioxidant properties of various solvent extracts of mulberry (Morus indica L.) leaves. Food Chemistry, 102, 1233-1240.

Arogba, S. S. (1997). Physical, chemical and functional properties of Nigerian mango (Mangifera indica) kernel and its processed flour. Journal of the Science of Food and

Agriculture, 73, 321-328.

Arogba, S. S. (2000). Mango (Mangifera indica) kernel: Chromatographic analysis of the tannin, and stability study of the associated polyphenol oxidase activity. Journal of Food Composition and Analysis, 13, 149156.

Durling, N. E., Catchpole, O. J., Grey, J. B., Webby, R. F., Mitchell, K.A., and Foo, L. Y. (2007). Extraction of phenolics and essential oil from dried sage (Salvia officinalis) using ethanol-water mixtures.Food Chemistry, 101, 1434-1441.

Imaida, K., Fukushima, S., Shivai, T., Ohtani, M., Nakanishi, K., and Ito, N. (1983). Promoting activities of butylated hydroxyanisole and butylated hydroxytoluene on 2-stage urinary bladder carcinogenesis and inhibition of g-glutamyl transpeptidase-positive foci development in the liver of rats. Carcinogenesis, 4, 885-889.

Lim, Y. Y.,and Murtijaya, J. (2007). Antioxidant properties of Phyllanthus amarus extracts as affected by different drying methods. LWT - Food Science and Technology, 40, 1664-1669.

Maisuthisakul, P., and Gordon, M. H. (2009). Antioxidant and tyrosinase inhibitory activity of mango seed kernel by product. Food Chemistry, 117, 332-341.

Mohamed, E. M., and Girgis, A. Y. (2005). Utilization of mango seed kernels for improving stability of some oils and biscuit production.Journal of Agricultural and Science, Mansoura University, 30(8),4625-4636.

Nepote, V., Grosso, N. R., and Guzma'n, C. A. (2002). Extraction of Antioxidant components from peanut skins. Grasas Y Aceites, 54(4), $391-395$.

Parmar, S.S., and Sharma, R. S. (1990). Effect of mango (Mangifera indica L) seed kernels on oxidative stability of ghee. Food Chemistry,35, 99107.

Pruthi, T.D., Narayanan, K.M. and Bhalerao, V. R. (1970). The role of milk phospholipids in the autoxidation of butterfat. Indian J. Dairy Sci., 23, 248-251.

Puravankara, D., Boghra, V., and Sharma, R. S. (2000). Effect of antioxidant principles isolated from mango (Mangifera indica $L$ ) seed kernels on oxidative stability of buffalo ghee (butter-fat). Journal of the Science of Food and Agriculture, 80, 522-526.

Slinkard, K., and Singleton, V. L. (1977).Total phenol analysis; automation and comparison with manual methods. American Journal of Enology and Viticulture, 28, 49-55.

Spigno, G., and De Faveri, D. M. (2007). Antioxidants from grape stalks and marc: Influence of extraction procedure on yield, purity and antioxidant power of the extracts. Journal of Food Engineering, 78, 793-801. 
Steele, R. G. D., and Torrie, J. H. (1980). Principles and procedures of statistics. New York: McGraw-Hill.

Yu, J., Ahmedna, M., and Goktepe, I.(2005). Effects of processing methods and extraction solvents on concentration and antioxidant activity of peanut skin phenolics. Food Chemistry 90, 199-206.

Zamorano, M., Pérez, J. I., Pavés, I. A., and Ridao, R. (2007). Study of the energy potential of the biogas produced by an urban waste landfill in Southern Spain. Renewable and Sustainable Energy Reviews, 11, 909-922.

Zein, R. E., El-Bagoury, A. A., and Kassab, H. E. (2005). Chemical and nutritional studies on mango see kernels. Journal of Agricultural Science, Mansoura University, 30(6), 3285-3299.





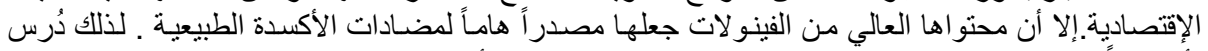

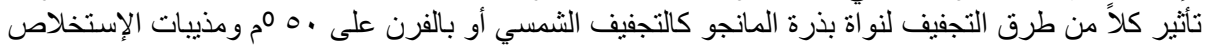



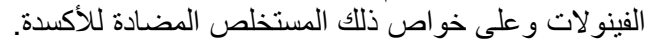

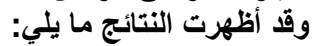

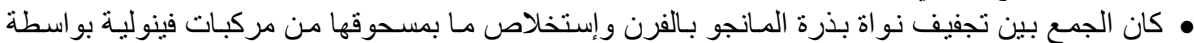

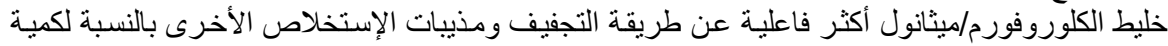

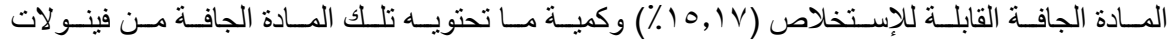

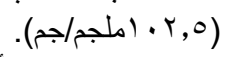



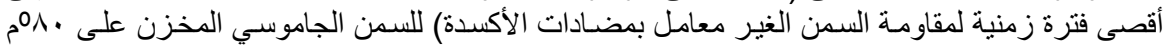

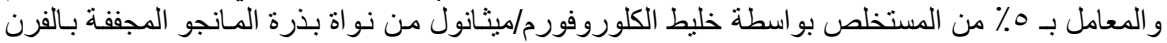

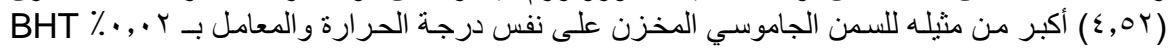

• عُرفت تسعة مركبات فينوليـة بالمستخلص السـابق وهى كورستين وكاتثـين وقانيلين وكو مـارين وتـانين


مما سبق يتضح انه يمكن استخدام أنوية بذور المانجو كمصدر للفيلـادات الأكسدة الطبيعية القادرة على أن تحل محل مضادات الأكسدة الصناعية. قام بتحكيم البحث

كلية الزراعة - جامعة المنصورة كلية الزراعة - جامعة القاهرة 